\title{
TÚMULOS Y JEROGLÍFICOS EN PAMPLONA POR LA MUERTE DE ISABEL DE FARNESIO
}

\author{
POR \\ JOSÉ JAVIER AZANZA LÓPEZ \\ Universidad de Navarra
}

In 1766 the funeral rites in memory of Queen Isabel de Farnesio were celebrated in the Cathedral of Pamplona, where all the social classes of the town assisted leaded by the Viceroy of Navarra, Count of Ricla. The Cathedral received a decorative covering in which sticked out the catafalque, a huge tower-shaped machine of decreasing bodies that covered the main part of the transept, in ground plan as well as in elevations. Numerous hieroglyphics, some of which have arrived to us, made the funerary monument «talk» about the deceased queen's virtues. Their mentor, the mercedarian father Asarta, is an expert of the Holy Scriptures, the classical, renaissance and baroque literature, and the emblems books, well known in the intellectual circles of Pamplona in the middle of 18th century.

Muerte de la reina y celebración de las exequias

El domingo 27 de julio de 1766 el Virrey y Capitán General del Reino de Navarra, don Ambrosio Funes de Villalpando, conde de Ricla, recibía una misiva firmada por el rey Carlos III en la que le notificaba la muerte de la reina madre Isabel de Farnesio acontecida el día 11 del mismo mes a las nueve y cuarto de la mañana ${ }^{1}$. La fatal noticia fue comunicada a los regidores y oidores del Real Consejo de la ciudad en la Junta Extraordinaria que tuvo lugar ese mismo día en la Sala de Consultas del Palacio Real; a partir de este momento se iniciaban los preparativos para la celebración de las honras fúnebres en sufragio por el alma de la reina difunta. Los primeros acuerdos adoptados fueron decretar por espacio de seis meses luto riguroso, «que es el mudo rethorico lenguaje con que explica el dolor sus afectos», y publicar un bando tanto en la capital del reino como en las cuatro cabezas de merindad haciendo partícipes a sus habitantes de tan luctuoso suceso ${ }^{2}$.

En los días siguientes se concretaron las fechas de los actos oficiales relacionados con la muerte de la reina. El 31 de julio a las once de la mañana tuvo lugar la visita de la Diputación al virrey para notificarle su pésame, acto que se desarrolló en la Sala del Dosel del Palacio Real ${ }^{3}$. Dos días más tarde fue el Regimiento de la ciudad el que transmitía su pésame al conde

\footnotetext{
1 Archivo Municipal de Pamplona (A.M.P.). Asuntos Regios. Sección de Exequias Reales. Leg. 4, nº 4. Año 1766.

2 Ibídem. Leg. 4, n 5.

${ }^{3}$ Archivo General de Navarra (A.G.N.). Actas de la Diputación, desde el 7 de Enero de 1761, a 29 de Diciembre de 1766. Tomo 18 , fol. 523
} 
de Ricla: a las tres y media de la tarde partió desde la Casa Consistorial una comitiva encabezada por los diez regidores y el secretario de la ciudad —el alcalde no figuraba «por no aver estilo»-, a los que acompañaban caballeros y vecinos, clarines y timbales, los tenientes de justicia y los maceros. Todos ellos vestían luto riguroso, y avanzaron por las calles de los Mercaderes, Santa Cecilia y Navarrería hasta alcanzar el Palacio Real, donde fueron recibidos por el virrey; una vez en su interior, el regidor don Francisco Ignacio de Gainza fue el encargado de leer el pésame de la ciudad ${ }^{4}$.

Los días 7 y 8 de agosto tuvieron lugar las exequias organizadas por el Real Consejo de Navarra, a las que acompañaron toda la etiqueta y protocolo característicos de estos ceremoniales fúnebres. El día 7 se celebró la función de vísperas, para lo cual a las dos y media se reunieron los tres tribunales, del Consejo, Corte Mayor y Cámara de Comptos, en la Sala Primera del Consejo; desde allí, y distruibuidos por su antigüedad, los ministros fueron en coches al Palacio Real, donde les esperaba el virrey acompañado de los más distinguidos militares y nobles del Reino. Una vez formada la comitiva, ésta se dirigió hacia la catedral, ocupando cada persona su lugar correspondiente conforme a su cargo y méritos. El inicio de las vísperas a las tres de la tarde vino marcado por el disparo de artillería, al que inmediatamente correspondieron «con el toque lamentable de sus campanas, tristes sonidos de inanimados bronces», todas las iglesias de la ciudad, incluida la catedral. Al día siguiente, desde las diez de la mañana se desarrollaron la vigilia, misa y honras acostumbradas. Ambas funciones contaron con la asistencia del conde de Ricla, quien ocupó una silla enlutada con sitial negro, al lado del Evangelio y frente al capelardente. Concurrieron también todos los cabildos y comunidades eclesiásticas, a las cuales se asignaron varias capillas catedralicias para la celebración de misas. El sermón y la oración fúnebre corrieron a cargo del guipuzcoano fray Jerónimo Elías Izuzquiza, Doctor en Teología, ex-prior de los conventos de Sangüesa y Tudela y prior del Convento de Carmelitas Observantes de Pamplona ${ }^{5}$. A través de esta última podemos captar perfectamente la imagen que se tenía de la monarquía, como se desprende de su texto laudatorio sobre la difunta reina en el que se destacan sus principales virtudes. Todo el discurso gira en torno al sentido de la frase latina «Mulier fortis obleciat at virum suum et annos vitae illius in pace implevit», extraida del Libro del Eclesiástico, 26, 2. El argumento consta de dos partes: la perfecta y heroína en lo político, y la perfecta y heroína en lo piadoso, con un claro sentido hiperbólico en la alabanza hacia la reina. La oración concluía resaltando el hondo pesar que había causado en toda Navarra la muerte de Isabel de Farnesio ${ }^{6}$.

El mismo 8 de agosto, una vez finalizadas las exequias del Consejo, dieron principio a las tres de la tarde las honras fúnebres organizadas por el Regimiento de la ciudad, que acudió a la catedral acompañado de la nobleza y de un numeroso concurso de vecinos para asistir a la celebración de las vísperas. Al día siguiente a partir de las diez de la mañana tuvo lugar la vigilia y misa solemne, acto al que fueron convidados el cabildo catedralicio, los correspondientes de las parroquias pamplonesas, los prelados de los conventos de la ciudad y sus extramuros, así como los rectores del Colegio de la Compañía y Descalzos, capellán mayor de las recoletas y vicario del hospital, de tal manera que cada comunidad celebrase misa cantada con responso por el alma de la reina difunta en las capillas señaladas por el cabildo de la catedral.

\footnotetext{
${ }^{4}$ A.M.P. Asuntos Regios. Leg. 4, $\mathrm{n}^{\mathrm{o}} 5$.

5 A.G.N. Archivo Secreto del Consejo Real. Título 1, Fajo 2, nº 3. Autos acordados del Consejo para la celebración de las exequias de la Reyna nra $S^{r a} D^{a}$ Ysabel Farnesio. 27 de julio de 1766.

${ }^{6}$ Oracion Fvnebre / De La Heroyna Quinta Isabel / Reyna de España, Esposa del Animo- /so Phelipe V, y Madre de nuestro Sa-/ bio Monarcha Carlos III. / Que en las Reales Exeqvias, Que El Dia / 8 de Agosto de este presente año celebró el Excelentissimo / Señor Conde de Ricla, y el Real Supremo Consejo / de Navarra, en la Santa Yglesia Cathedral de I Pamplona... En Pamplona: En la Oficina de Joseph Miguel de / Ezquerro, Impressor de los Reales Tribunales.
} 
En este caso el sermón fue encargado al padre Ramón de Aguirre, lector de Teología de la Compañía de Jesús ${ }^{7}$.

\section{El levantamiento del túmulo o catafalco}

La magnificencia y aparato que el ceremonial funerario requería implicaba el esfuerzo de diferentes personas y oficios, desde los responsables de su organización, hasta los sastres, tapiceros, cereros, carpinteros, ensambladores, pintores, intelectuales, oradores, y finalmente grabadores e impresores que dejaban constancia de tan magno acontecimiento. El interés primordial de todos ellos se dirigía a la gran ceremonia que tendría lugar en la catedral, a la cual se revestía con un despliegue decorativo del que formaban parte tapices y ornamentos, telas y pinturas, sedas y bayetas. La pieza más destacada de todo este engranaje la constituye desde el siglo XVI una gigantesca arquitectura de tipología variada, que recibe la denominación de túmulo o catafalco.

El mismo día en que se tuvo noticia de la muerte de la reina se iniciaron los preparativos para la colocación del túmulo en la santa iglesia catedral, que sería el mismo tanto para las funciones del Consejo Real como para las del Regimiento. Para tal fin fueron comisionados los regidores don Antonio Ramón de Antoñana y don Martín Felipe Lacarra, a quienes se les encargaba «ver y registrar el capelardente que la ciudad compró a la Compañía» ${ }^{8}$. En efecto, ya desde mediados del siglo xviII, el Regimiento había determinado solicitar «al Colexio de la Compañía el capelardente que éste tiene para las funciones funerales de los militares, respecto a estar sin uso por biexo y muy maltratado el de la ciudad». La petición a la Compañía de Jesús aparece reflejada por primera vez en 1746 con motivo de las exequias de Felipe V, y se repite en funerales posteriores. Ya en 1760 la Ciudad acabó comprando el túmulo a los jesuitas, siendo tasado en 324 reales por los maestros carpinteros José de Huici y Francisco de Aguirre. De esta manera, en la mayor parte de las exequias reales que se celebraron en el siglo XVIII los carpinteros de la ciudad levantaron una y otra vez el mismo túmulo procedente del Colegio de la Compañía, aunque «con mayor elebacion y magnifiziencia», lo cual nos da a entender que debió de ser renovado y ampliado para adaptarlo al espacio catedralicio; esta circunstancia se produjo en los funerales de Felipe V (1746), Bárbara de Braganza (1758), Fernando VI (1759), María Amalia de Sajonia (1760) e Isabel de Farnesio (1766) 9 .

La labor de colocación del capelardente fue encomendada a los maestros carpinteros José Antonio de Huici — quien ya había tomado parte en su montaje en las cuatro ocasiones precedentes- y Francisco de Aguirre; quedó emplazado «en medio del espaciosissimo Crucero de la Iglesia Cathedral», entre las rejas de la capilla mayor y del coro, abarcando la mayor parte de él, tanto en planta como en alzados. Alrededor de la máquina funeraria se distribuían los miembros de las instituciones civiles y eclesiásticas, quienes ocupaban los asientos a ellos destinados con un orden rigurosamente jerárquico.

\footnotetext{
${ }^{7}$ Las relaciones de exequias organizadas tanto por el Consejo Real como por el Regimiento de la ciudad llegaron a imprimirse en las imprentas de José Miguel de Ezquerro y Antonio Castilla respectivamente; no nos ha sido posible consultar ninguna de ellas, aunque Pérez Goyena recoge la existencia de un ejemplar de las exequias del Consejo — del que hace una breve reseña- en la Biblioteca del Colegio de Jesuitas de Tudela. A. Pérez Goyena, Ensayo de bibliografía navarra, Tomo Tercero, Pamplona, 1951, pp. 273-75.

${ }^{8}$ A.M.P. Asuntos Regios. Leg. $4, \mathrm{n}^{\circ} 5$.

${ }^{9}$ El empleo del mismo túmulo en sucesivas exequias reales no era algo excepcional, sino que resultó frecuente en la elaboración de estas estructuras fúnebres a lo largo de los siglos xVII y xVIII, sobre todo en ámbitos provinciales. Dicha circunstancia suponía una clara limitación a la libertad creadora del artista, a la vez que impedía una evolución más rápida de los elementos arquitectónicos y decorativos que configuraban los catafalcos. V. Soto Caba, Catafalcos reales del Barroco Español, Madrid, U.N.E.D., 1991, pp. 184-88.
} 
Ha llegado hasta nosotros un diseño del catafalco real realizado por el propio José Antonio de Huici, quien dibujó su planta y alzado «a fin de que qualquiera Maestro Carpintero con facilidad lo pueda poner y tenga la más puntual noticia del modo en que se plantifica, velas y achas que se emplean en él, de la manera que se enluta, pone el púlpito, y espacio que se deja para los responsos y demás que corresponde a tan serio acto» ${ }^{10}$ (Fig. 1). El dibujo, además de mostrar la estructura del monumento funerario, delimita los espacios reservados a las diferentes autoridades que presenciaban y presidían el acto. De acuerdo con el diseño de Huici, el túmulo se configura como una enorme máquina de tipo turriforme, formada por un primer cuerpo a modo de basamento de planta cuadrada de 28 pies de lado y 8 de alto, sobre el que se elevan otros cinco cuerpos arquitectónicos decrecientes con cirios, velas y candelabros; encima de todos ellos se disponía la tumba real, «que es un imaginario sepulcro ausente el Cadáver». El basamento consta de dos escalinatas, una hacia la capilla mayor y otra hacia el coro, rematando en una balaustrada superior; a los lados de la escalera del coro se disponen sendos altares portátiles que dan a la parte del Evangelio y de la Epístola respectivamente, formados por dos mesas de nogal «con dos cuadros, uno de Nuestra Señora y otro de San Fancisco Javier, con marcos dorados y uniformes», en los cuales el capellán de la ciudad y otro sacerdote celebraban misa rezada a un mismo tiempo. Próximo al altar de San Francisco Javier quedaba un púlpito portátil desde el cual el ministro dirigía la oración fúnebre por el alma del difunto, «observando en esto el estilo antiguo, para más authoridad de la Función Regia, pues en los entierros de los Emperadores Romanos llevaban el Sugeto, o Púlpito, en andas a la cabecera del Imperial Feretro, de donde el elocuente orador predicaba sus alabanzas».

Los cinco cuerpos superiores se decoraban con bayetas y paños bordados de terciopelo negro, y en el frente de la tumba que daba al coro se colocaba un esqueleto de gran tamaño pintado en lienzo, clara alusión a la muerte «que hace alarde de su poder y glorioso vencimiento»; encima quedaban un cetro y una corona real que representaban la majestad y el dolor, sobre una almohada morada o negra que se sacaba de la sacristía mayor. Telas y papeles pintados con calaveras y coronas, emblemas y jeroglíficos colocados en diferentes partes del catafalco otorgaban a las pompas fúnebres el carácter emblemático propio de las exequias de los monarcas. Se trata en definitiva de una estructura sumamente austera, cuya espectacularidad viene proporcionada por su programa iconográfico y por la multitud de «funestas antorchas» que enmascaraban por completo su arquitectura, símbolo de la luz de Dios y del alma de Isabel que no se apaga: 106 velas y 12 hachas figuraban sobre la barandilla, antepechos y pasamanos del primer cuerpo, mientras que en los cinco cuerpos restantes se distribuían 138 velas y 20 hachas en los ángulos. Con tal número de velas y cirios, el catafalco era descrito como «ardiente pira» 0 «fogoso y encendido Mongibelo de trémulas medrosas llamas». Merced a su vibrante iluminación se alcanzaba ese ambiente tétrico «lleno de sombras y luces» que requería toda función funeral, a la vez que permitía leer las inscripciones de emblemas, jeroglíficos y poesías distribuidos en los cuerpos del túmulo.

\section{El túmulo como elemento «parlante»: los jeroglíficos}

La composición del túmulo no requería tan sólo de los maestros carpinteros encargados de levantar su arquitectura, sino que resultaba imprescindible la intervención de un mentor instruido en los símbolos y alegorías, responsable del «revestimiento ideológico» de la máquina.

\footnotetext{
${ }^{10}$ Arch. Catedral de Pamplona. Sindicatura, 28-8-1766, s/n. Planta y explicacion del tumulo que de años aca se pone en la Santa Iglesia en las Exequias Reales. Huici realizó el diseño el 28 de agosto de 1766, una vez finalizadas las exequias en memoria de Isabel de Farnesio.
} 

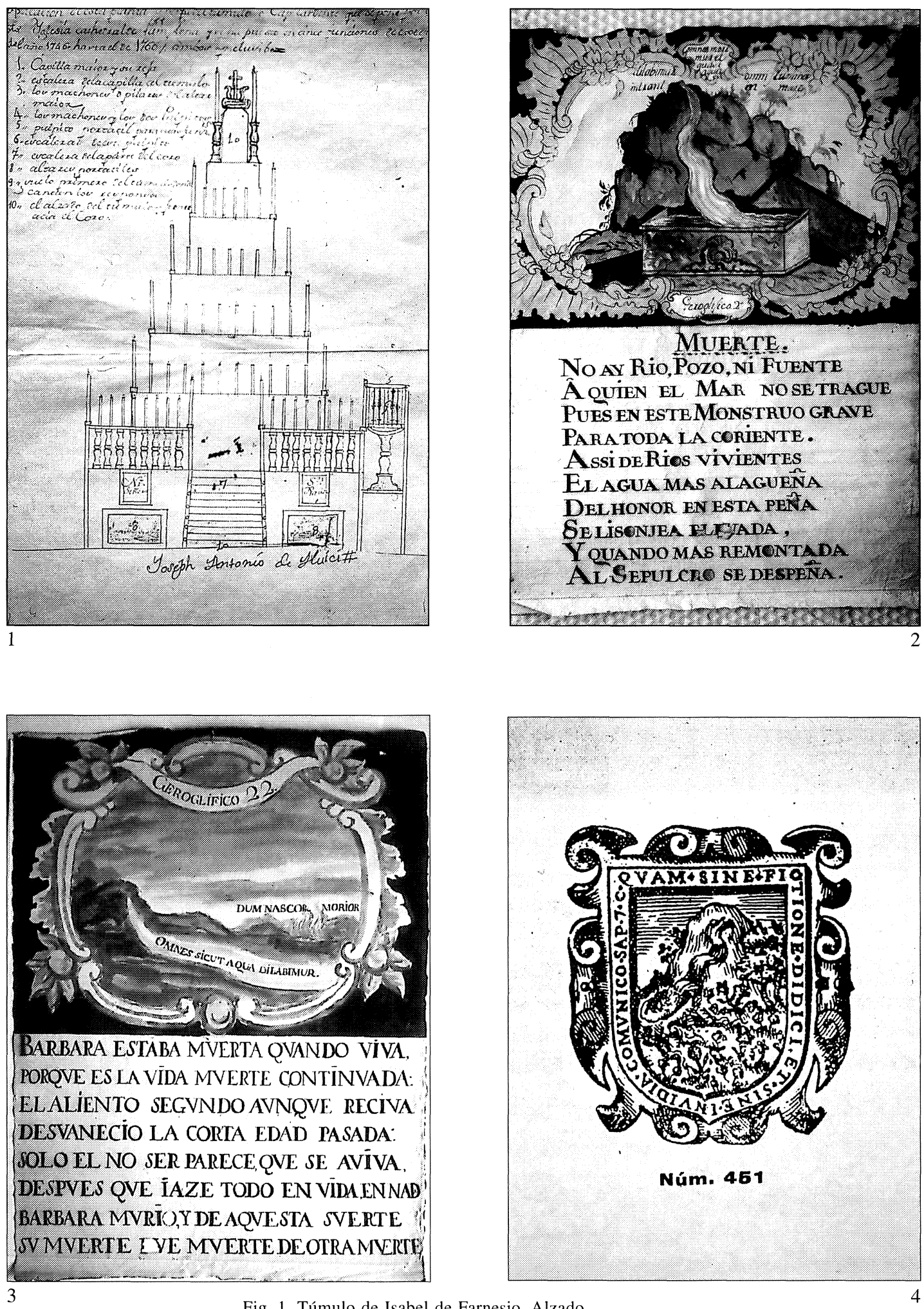

Fig. 1. Túmulo de Isabel de Farnesio. Alzado.

Fig. 2. Jeroglífico $\mathrm{n}^{\circ} 2$. «Muerte».

Fig. 3. Jeroglífico $\mathrm{n}^{\circ} 22$ del túmulo de Bárbara de Braganza.

Fig. 4. Divisa del impresor Pedro Cabarte. 
Elemento fundamental de los túmulos eran los emblemas, empresas, jeroglíficos, laberintos, acrósticos y cabalísticos, que hacían «hablar» al monumento funerario del poder y de la gloria del difunto, convirtiéndose así en el vehículo principal para la transmisión de mensajes al espectador ${ }^{11}$; todos ellos eran ideados por eruditos que se inspiraban en diversas fuentes como las Sagradas Escrituras, la mitología, la historia o los escritos griegos y latinos, así como los libros de empresas o emblemas, muy abundantes en esta época y cuyo conocimiento en los ámbitos intelectuales pamploneses nos consta a través de los inventarios de bibliotecas conservados ${ }^{12}$

Al igual que en las exequias reales anteriores, también con motivo de la muerte de Isabel de Farnesio se elaboraron complejos programas iconográficos con alusiones a la reina difunta. Y es que, así como el túmulo era el mismo tanto en las celebraciones del Consejo Real como del Regimiento de la ciudad, los jeroglíficos y emblemas cambiaban, encargando cada institución los suyos propios y colocándolos en la función correspondiente. Deberíamos preguntarnos hasta qué punto estos jeroglíficos eran comprendidos por la mayor parte de la población pamplonesa, o si su correcta interpretación estaba reservada tan sólo a una minoría selecta y culta capaz de descifrar completamente el significado de los símbolos y desentrañar el hiperbólico lenguaje que los explicaba en las Relaciones; aunque esta segunda hipótesis parece más acertada, no debemos olvidar que, como afirma Pedraza, «los hombres del Barroco, cualquiera que fuese su condición, vivían inmersos en una cultura impregnada de conceptismo y que la agudeza, la adivinanza, el juego de palabras y conceptos, les eran completamente familiares» ${ }^{13}$. Además, en el caso de los jeroglíficos pamploneses se produce con relativa frecuencia la copia de los de exequias anteriores, dado que era usual que los mentores consultasen relaciones de años pasados para poder emular su esplendor, de tal manera que el espectador acababa familiarizándose con ellos y con su significado, dada su reiteración ${ }^{14}$. En definitiva, los asistentes a la función religiosa asimilaban de diferente manera el espectáculo que ante ellos se desplegaba dependiendo de su nivel cultural, tal y como hacía constar el cronista en los funerales de Carlos III: «siendo en unos el asombro efecto de los ojos, y en otros de la razón».

Centrándonos en las exequias de Isabel de Farnesio, el Consejo Real encargó la elaboración del programa iconográfico a don Antonio Pardo, Abogado de los Tribunales Reales; su ejecución material corrió a cargo del pintor Juan Antonio Logroño, a quien se le pagaron 152 reales «por el trabajo de haber pintado varios jeroglíficos y otras varias figuras en el túmulo de

\footnotetext{
" Como afirma el profesor Mínguez, «la capacidad de atracción que supone la conjunción de la imagen y la palabra y su carácter de divertimento convierte a los jeroglíficos en el elemento favorito en la decoración de una estructura efímera». V. Mínguez, Emblemática y cultura simbólica en la Valencia barroca, Valencia, 1997, p. 21.

12 Así por ejemplo, en el inventario realizado en 1684 de la librería de Lorenzo Coroneu, mercader de libros vecino de Pamplona, figuraba una de las ediciones realizadas en Amberes de las Empresas Políticas de Saavedra Fajardo, un ejemplar de la Emblemata Regio Politica de Juan de Solórzano, y otro de los Emblemas de Alciato. También Vicente Ignacio de Mutiloa contaba con un ejemplar de las empresas de Saavedra Fajardo en su biblioteca, inventariada en 1726. Por su parte, en el inventario de la librería de los marqueses de San Miguel, de 1734, aparecían sendos ejemplares de las empresas de Saavedra Fajardo y de los Emblemas Morales de Juan de Horozco. Y en el inventario de bienes del médico José Joaquín de Aoiz realizado en 1753 figuraban tres tomos con las obras de Saavedra Fajardo y un ejemplar de las Empresas Sacras del jesuita Francisco Núñez de Cepeda. Archivo Diocesano de Pamplona (A.D.P.). C/1436 - No 2, fols. 458-77. A.G.N. Protocolos Notariales. Pamplona. José de Vegué, 26-2-1726. P. Andueza, El Palacio de los Marqueses de San Miguel de Aguayo en Pamplona. Memoria de Licenciatura sustentada en la Universidad de Navarra. A.G.N. Protocolos Notariales. Pamplona. Fermín Istúriz, 1753, doc. $n^{\circ} 61$.

13 P. Pedraza, Barroco efímero en Valencia, Valencia, 1982, p. 60. También desarrolla esta cuestión G. Ledda, «Los jeroglíficos en el contexto de la fiesta religiosa barroca», Actas del I Simposio Internacional de Emblemática, Teruel, Instituto de Estudios Turolenses, 1994, págs. 593-97. Y R. Escalera Pérez, «La emblemática española en las decoraciones efímeras de los túmulos granadinos. Siglos xvII y xviI», Literatura Emblemática Hispánica. Actas del I Simposio Internacional, La Coruña, 1996, pp. 429-45.

${ }_{14}$ En este sentido, Varela señala que «algunos temas iconográficos se repiten hasta la saciedad», concluyendo que desde mediados del siglo Xvir el lenguaje emblemático se hallaba muy codificado. J. Varela, La muerte del rey, Madrid, Turner, 1990, pp. 110-12.
} 
las exequias que se han celebrado» ${ }^{15}$. El mensaje se componía de las ocho bienaventuranzas con lemas latinos y versos castellanos, y diversos jeroglíficos como una corona, la monarquía de España, la muerte o la riqueza, que se explicaban en décimas. Podía leerse también un acróstico en exámetros que configuraba con las primeras letras de cada verso estas palabras: «Domina Isabel Farnesio Reyna de España». El programa iconográfico concluía con la siguiente reflexión en torno a la muerte de la reina: «Si ayer mandé con imperio / Corona sobre corona, / Ya en mis reinos se corona / Hoy de la muerte el Imperio. / Sólo os queda el refrigerio / Que en treinta y tres letras brilla / Leedlas, y ver cual se humilla / Eclipsado rosicler, / Frío azar, hoy la que ayer / Fue flor de la Maravilla».

En cuanto al Regimiento de Pamplona, el mentor fue el padre Juan Gregorio González de Asarta, del convento de la Merced de Pamplona, quien elaboró un programa iconográfico compuesto por treinta y ocho jeroglíficos en los que se mezclan alusiones a la muerte de Isabel con aquellas virtudes que adornaron a la difunta. En su ejecución material tomaron parte dos personas, Pedro José Martínez Musitu, que escribió el texto, y el pintor y dorador Fermín Rico, que llevó a cabo la labor pictórica.

En el Archivo Municipal de Pamplona se custodian algunos de los jeroglíficos farnesinos, testimonio fiel y directo de lo que constituyó la fiesta barroca en Navarra ${ }^{16}$. Elaborados en papel a modo de tarjetones, cada uno mide $59 \times 44 \mathrm{~cm}$, y su estado de conservación es regular, ya que se aprecian en ellos las huellas del deterioro producido por la acidez de las tintas y por el humo y fuego de las velas que ardieron en su proximidad en el túmulo. Cada jeroglífico consta de un lema o mote en lengua latina, un cuerpo - que incluye símbolos o figuras humanas- enmarcado en un fondo negro sobre el que se recorta una bella cartela de rocallas de color amarillo, y un epigrama acompañado de una poesía castellana, características que con mayor exactitud los definen como empresas; en ocasiones una frase latina, situada en la parte superior del cuerpo, amplía la idea recogida en el mote. Aunque en algunos casos los jeroglíficos eran copiados directamente de los libros de emblemas, resulta más habitual que éstos sirvan de inspiración al mentor, que puede tomar de ellos algunos aspectos o puede crear uno nuevo sin olvidar el sentido inicial de los símbolos que ha utilizado; esta última circunstancia es la que acontece en el caso de los jeroglíficos pamploneses, e incluso en ocasiones son varias fuentes las que sirven para configurar un único jeroglífico.

El contenido ideológico del túmulo se iniciaba con un soneto acróstico en memoria de la reina difunta, cuyas iniciales componían la frase «A LA REYNA YSABEL» ${ }^{17}$. El Jeroglífico $\mathbf{n}^{\circ} \mathbf{2}$ tiene como mote «Omnes morimur, et quasi aqua», y hace referencia a la idea de la Muerte, tal y como refiere la décima del epigrama:

No hay Río, Pozo ni Fuente / a quien el mar no se trague / pues en este Monstruo Grave / Para toda la Corriente. /

Assí de Ríos vivientes / El agua más alagüeña /

Del honor en esta peña / se lisonjea elevada, /

Y quando más remontada / al sepulcro se despeña.

\footnotetext{
15 A.G.N. Archivo Secreto del Consejo Real. Título 1, Fajo 2, $\mathrm{n}^{\circ}$ 4. Recivos de lo gastado en las exequias de la $S^{r a}$ Reyna Doña Ysavel Farnesio. Año de 1766.

${ }^{16}$ Nuestro agradecimiento a D. José Luis Molins Mugueta, archivero municipal, por las facilidades a la hora de la consulta de los jeroglíficos y la obtención del material fotográfico.

${ }_{17}$ El acróstico refería lo siguiente: A quién dedicas Ymperial Ciudad / Lúgubre Tumba, Tétrico Panteón? / A quién consagra tu noble corazón / Real Cenotaphio, en fina lealtad? / Essa del Monte grave Magestad / Y de tus timbres índice y blasón / Nos pide en muda fúnebre expresión / Atención a tan cruel fatalidad. / Ya murió: (Qué quebranto! Qué rigor) / Sabia Matrona, Liberal y Fiel / Avivando en los pechos el dolor: / Brote pues agua, el pecho más cruel / Explique ya, que falleció (qué horror) / La Reyna Madre, Magnánima Ysabel.
} 
En su cuerpo aparece una corriente de agua que desde lo alto de una peña cae al interior de un sepulcro abierto cuya lápida reposa sobre las rocas (Fig. 2). Su explicación, «Dilabimur omni flumina intrant in mare», está tomada del Eclesiastés 1, 7, donde se afirma que «todos los ríos van al mar, pero el mar nunca se llena», en alusión a la transitoriedad de las cosas del mundo y fugacidad de nuestra existencia. Asimismo, la comparación de la vida con una corriente de agua es tema que evoca una de las más conocidas coplas compuestas por Jorge Manrique a la muerte de su padre, concretamente la $n^{\circ}$ III: «Nuestras vidas son los ryos / que van a dar en el mar / que es el morir; / allí van los señoríos / derechos a se acabar / y consumir. / Allí los ríos caudales, / allí los otros, medianos, / y más chicos, / allegados, son yguales, / los que biven por sus manos / y los ricos» ${ }^{18}$. Por consiguiente, tanto la copla de Manrique como el epigrama del jeroglífico pamplonés hacen referencia a una muerte que no perdona a nadie, ni a vasallos ni a monarcas, llegando a todos por igual. En este sentido debemos recordar que los pamploneses se encontraban familiarizados con la identificación de la vida con una corriente de agua, puesto que el tema ya había sido representado en uno de los jeroglíficos elaborados en 1758 con motivo de las exequias de la reina Bárbara de Braganza, bajo el mote «Omnes sicut aqua dilabimur» (Fig. 3) En ambos casos, la representación pictórica del tema puede estar inspirada en la empresa XL de Saavedra Fajardo, «Quae tribuunt tribuit», que recoge una montaña de la que manan varios arroyos que distribuyen su agua por el valle; también guarda relación con la divisa del impresor aragonés Pedro Cabarte (activo en Huesca y Zaragoza entre 1612 y 1632), en la que figura una montaña por cuya pendiente desciende una corriente de agua que hace brotar flores y árboles ${ }^{19}$ (Fig. 4).

El Jeroglífico no 3 presenta el mote «Quod es, fui: quod sum, eris», y en él aparece un sepulcro entreabierto con la lápida removida en cuyo interior se aprecia un esqueleto coronado (Fig. 5). La décima que compone el epigrama nos dice:

Como era sólo figura / Del Reyno la pompa ufana / pasó, como sombra vana, / Y paró en la sepultura: / La Corona, la Hermosura / fueron fingidos placeres / Y assí (si acertarlo quieres) / oye la lección que te doy. Tu has de ser lo que yo soy, / pues yo fui lo que tú eres.

La relación del sepulcro con la muerte resultaba frecuente en la literatura emblemática de la época, y casi todos los autores dedicaron alguna de sus empresas a representar gráficamente el tema. En el caso del jeroglífico pamplonés, la sepultura entreabierta nos permite ver el contenido de su interior, que no es sino el esqueleto de la propia reina todavía con la corona sobre su cabeza; Isabel ha sido víctima de la muerte, que no respeta cetros ni coronas. Se trata en consecuencia de un claro mensaje de advertencia a todos cuantos lo contemplaban, para que tuvieran presente la caducidad de los logros de este mundo y la certeza de la muerte.

El Jeroglífico $\mathbf{n}^{\mathbf{0}} \mathbf{5}$, bajo el mote «Ferocitate imitis», tiene como protagonista a un joven de rostro melancólico tocado con una corona vegetal al que una serpiente muerde el corazón (Fig. 6). La empresa nos quiere transmitir la idea del inmenso dolor que había embargado a los habitantes de Pamplona al recibir la noticia de la muerte de Isabel de Farnesio, tomando

\footnotetext{
18 J. Manrique, Coplas que hizo Jorge Manrique por la muerte de su padre, Copla III, Barcelona, Promociones y Publicaciones Universitarias, 1991.

${ }^{19}$ F. Vindel, Escudos y marcas de impresores y libreros en España durante los siglos XV a XIX, Barcelona, Ed. Orbis, 1942, p. 351. El texto de la divisa, tomado del Libro de la Sabiduría, cap. 7, vers. 13, hace referencia a la misma: «Quam sine fictione didici, et sine invidia comunico». Y curiosamente en el mismo capítulo se alude a la muerte, que en palabras del rey Salomón es común a todo hombre sin importar su categoría social: «ningún rey comenzó de otro modo su existencia, pues el comienzo y el final de la vida son iguales para todos».
} 

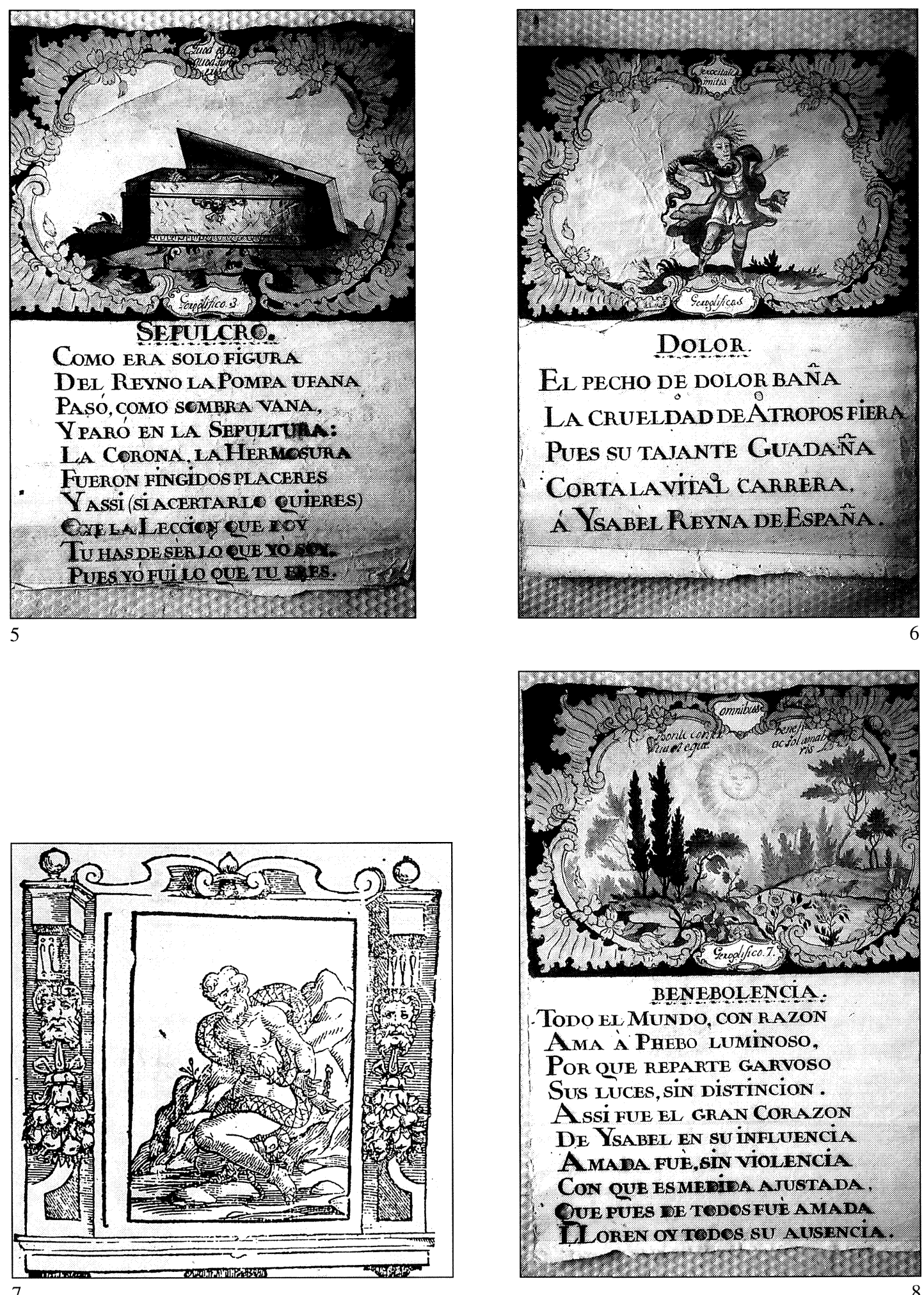

Fig. 5. Jeroglífico $\mathrm{n}^{\circ}$ 3. «Sepulcro».

Fig. 6. Jeroglífico $\mathrm{n}^{0}$ 5, «Dolor».

Fig. 7. Cesare Ripa. Iconología. Dolor.

Fig. 8. Jeroglífico $\mathrm{n}^{\circ}$ 7. «Benevolencia» 
inmediatamente el luto, revistiendo los edificios de la ciudad de bayetas y paños negros, y asistiendo en numeroso concurso y con sincera consternación a las exequias organizadas en memoria de la reina difunta. En esta ocasión el epigrama es una quintilla:

El pecho de dolor baña / la crueldad de Atropos fiera / pues su tajante guadaña / corta la vital carrera, / a Ysabel Reyna de España.

La representación está tomada de la Iconología de Ripa, obra en la que el Dolor se simboliza como un hombre medio desnudo, de rostro melancólico, con manos y pies encadenados y una serpiente enroscada alrededor del cuerpo que fieramente le muerde el costado ${ }^{20}$ (Fig. 7). La identificación del dolor con esta imagen no resultaba desconocida a los pamploneses, puesto que ya en las exequias organizadas en 1746 por el Consejo Real con motivo de la muerte de Felipe V aparecía en uno de los jeroglíficos la figura del Dolor como un «Joven Melancólico ceñido de una sierpe, que le mordía el corazón».

El Jeroglífico $\mathbf{n}^{\mathbf{0}} \mathbf{7}$, bajo el mote, «Omnibus», hace alusión a la benevolencia de la reina difunta, tal y como recoge el epigrama:

Todo el mundo, con razón / Ama a Phebo luminoso, /

Porque reparte garvoso / sus luces, sin distinción. /

Assí fue el gran corazón / de Ysabel en su influencia. /

Amada fue, sin violencia / con que es medida ajustada, /

Que pues de todos fue amada / Lloren oy todos su ausencia.

El jeroglífico muestra en su cuerpo un sol que inunda con sus rayos un paisaje campestre con suaves colinas, árboles y arbustos, y flores; en la parte superior, alrededor del sol, el texto latino refiere: «Sponte confer benefitia, et eque ac sol amaberis» (Fig. 8). Sin lugar a dudas, de entre todos los símbolos aprovechados por los emblemistas en sus composiciones para representar la idea de benevolencia y generosidad destaca el sol; también la identificación de la monarquía con el astro rey estaba muy arraigada ya desde el siglo xvi, convirtiéndose en la mejor representación ideológica de la realeza ${ }^{21}$. En nuestro caso el sol alude a la liberalidad y benignidad de Isabel, quien procuró el bien de su pueblo sin hacer distinciones, y por ello alcanzó el reconocimiento y cariño de todos sus súbditos.

Este significado solar es recogido por Juan de Horozco y Covarrubias en sus Emblemas Morales (1589), cuyo emblema XXVII del Libro Segundo representa un sol que con su claridad ilumina un paisaje, dando a entender que ninguna cosa buena puede haber en el mundo que no proceda de su mano, «con tanta generalidad que a ricos y a pobres sustenta y recrea de una manera, sin que tengan más parte en él los Príncipes de la que tienen los pobres»; en este caso, la figura del sol es equiparada a la infinita bondad de Dios ${ }^{22}$. Por su parte Sebastián de Covarrubias, en sus Emblemas Morales (1610) titula su emblema $n^{\circ} 8$ «Omnibus Idem», y en su cuerpo aparece un sol en lo alto del cielo, cuyos rayos alcanzan a las ciudades de Babel y Jerusalén. Su epigrama explica que la luz del sol se distribuye por igual para todos, «sin hazer división, o diferencia», refiriéndose al capítulo 5, versículo 45, de San Mateo, donde el Evangelista dice que Dios «hace salir el sol sobre buenos y malos» ${ }^{23}$.

${ }^{20}$ C. Ripa, Iconología, T. I, Madrid, Akal, 1987, pp. 292-93.

21 V. Mínguez, «Los emblemas solares, la imagen del príncipe y los programas astrológicos en el arte efímero», Actas del I Simposio Internacional de Emblemática, pp. 209-54.

22 J. de Horozco, Emblemas Morales, Libro Segundo, Emblema XXVII, Segovia, impresso por Juan de la Cuesta, 1589.

23 S. de Covarrubias, Emblemas morales, Emblema 8, Madrid, 1610. 


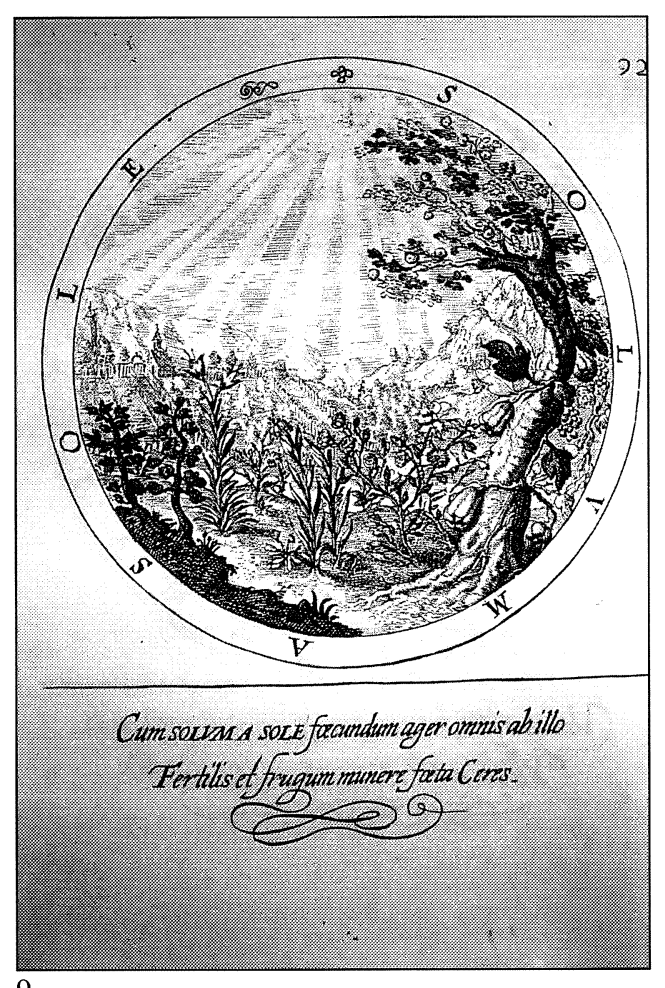

9

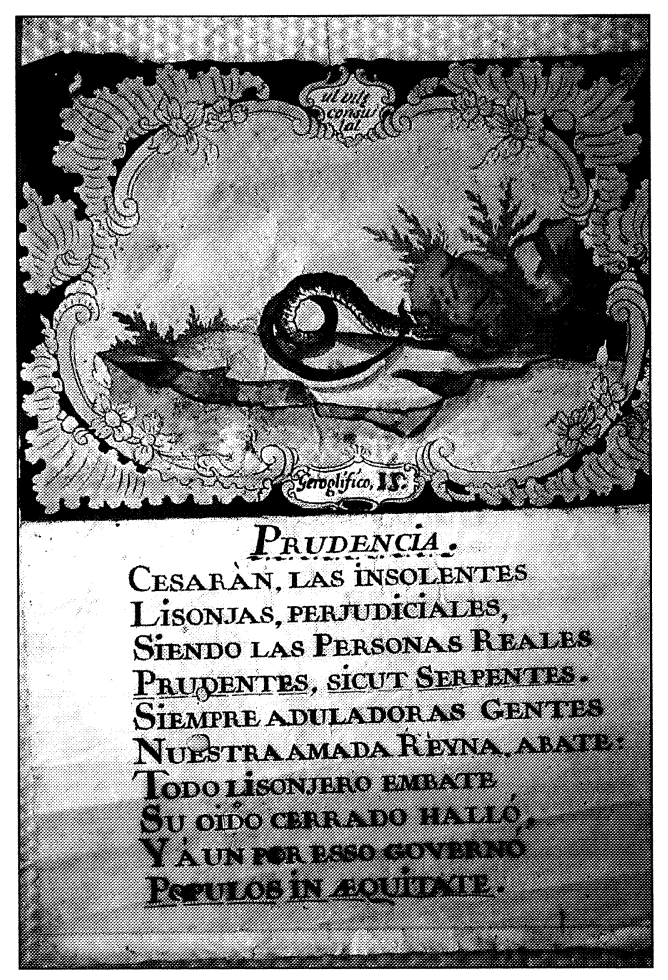

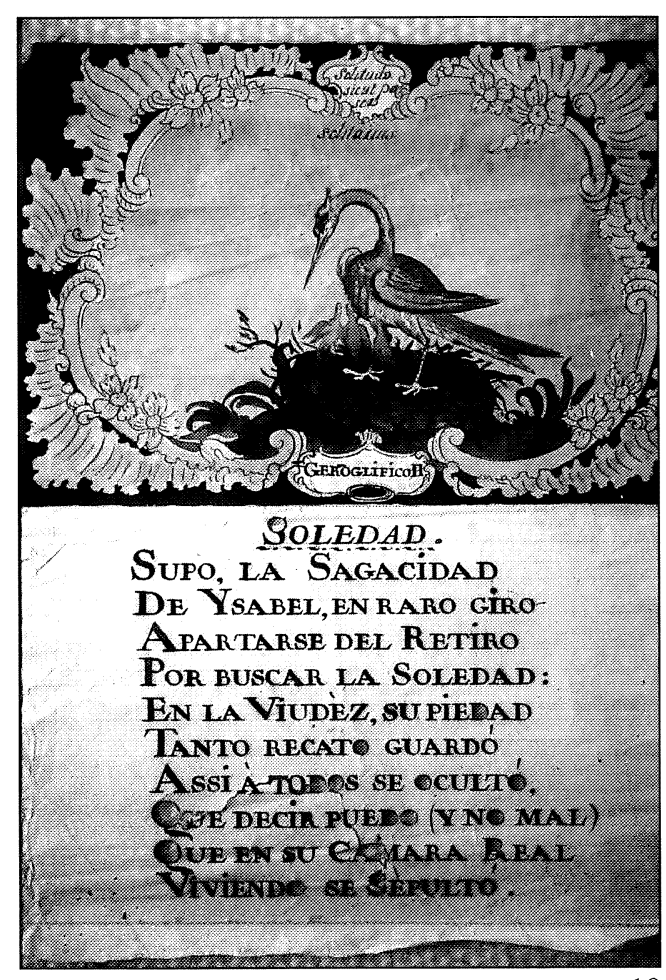

10

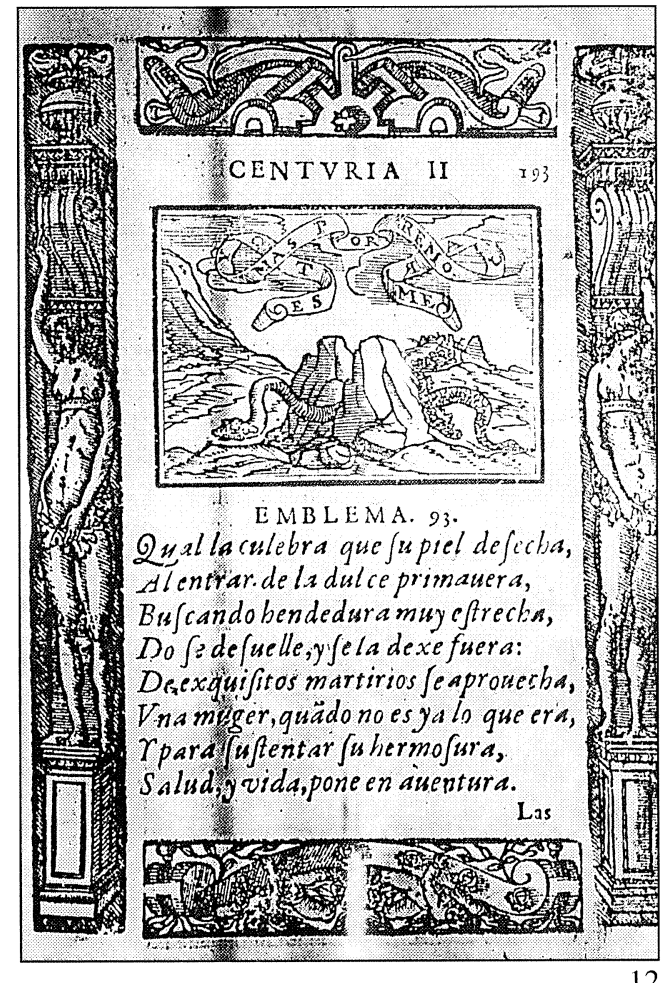

12

11

Fig. 9. Gabriel Rollenhagen. Nucleus emblematum, emblema $\mathrm{n}^{\circ} 92$

Fig 10. Jeroglífico $n^{\circ} 11$, «Soledad».

Fig. 11. Jeroglífico $n^{\circ} 15$. «Prudencia».

Fig. 12. Sebastián de Covarrubias. Emblemas Morales, emblema $n^{\circ} 93$ 
Nuevamente encontramos el emblema solar en Gabriel Rollenhagen, concretamente en el emblema 92 de su Nucleus emblematum (1611), en el que bajo el mote «Solum a sole» aparece un sol que distribuye con generosidad sus rayos sobre un paisaje con flores, árboles y campos sembrados (Fig. 9); también el emblema 58, «Post tentationem consolatio», nos ofrece un paisaje similar ${ }^{24}$. Asimismo Baños de Velasco, en la empresa XIX de su L. Anneo Seneca ilustrado en Blasones políticos y morales (1670), representa este mismo tema, y alude a la liberalidad del rey, insistiendo en que la gratitud de los súbditos debe ser para con el monarca y no con los intermediarios de su benevolencia ${ }^{25}$.

En el Jeroglífico $\mathbf{n}^{\mathbf{0}} \mathbf{1 1}$ aparece un pelícano en su nido, de cuyo pecho mana sangre con la que se alimentan sus crías (Fig. 10). Tanto el mote «Solitudo sicut paser» como el término «Solitarius» quieren transmitir la idea de Soledad, tal y como apreciamos en la décima que compone el epigrama:

Supo, la sagacidad / de Ysabel, en raro giro / apartarse del retiro / por buscar la soledad: / en la viudez, su piedad / tanto recato guardó / Assí a todos se ocultó, / Que decir puedo (y no mal) / Que en su Cámara Real / viviendo se sepultó.

Muy probablemente, el contenido ideológico del jeroglífico alude a la situación que atravesó la reina tras la muerte de su esposo Felipe V. En efecto, en 1747, Isabel de Farnesio fue «invitada» a abandonar la Corte y se le dieron a elegir varios lugares en los que fijar su residencia; finalmente optó por recluirse en San Ildefonso, monasterio en el que estaba enterrado su esposo, y donde permaneció hasta el advenimiento al trono de su hijo Carlos III. A este destierro forzoso le condujo su carácter despótico, su ambición de mando, y su animosidad y envidia hacia Fernando VI y Bárbara de Braganza, a la cual acusó de mantener amistad íntima con Farinelli ${ }^{26}$. Por tanto, Isabel de Farnesio fue obligada a desaparecer del escenario público, y de ahí la idea que refiere el emblemista de sepultarse en vida.

En el contexto del jeroglífico, el término «paser» debe entenderse como «passer solitarius» o pájaro solitario, un ave de la tribu de los pájaros, con plumaje azulado oscuro, negro en las alas y pardo en la cola, al que algunos autores han querido identificar con el mirlo azul ${ }^{27}$. El Tesoro de la Lengua Latina recoge una de las acepciones de passer como «ave solitaria», remontándose en ella a las Sagradas Escrituras y a los autores latinos ${ }^{28}$. Así por ejemplo en el versículo 8 del Salmo 102 se alude a la soledad del pájaro: «Estoy desvelado, gimiendo como pájaro solitario en el tejado». El salmista quiere expresar la soledad del judío en el destierro de Babilonia, y elige al pájaro como símbolo de tal soledad. Ya en el siglo Xvi, Santa Teresa de

\footnotetext{
${ }^{24}$ G. Rollenhagen, Nucleus emblematum selectissimorum quea Itali vulgo impressas vocant, París, Aux Amateurs des livres, 1611 (reimpresión 1989). Gabriel Rollenhagen es un escritor y jurista alemán poco conocido, que nació en Magdeburgo en 1583 y murió hacia 1620. Estudió derecho en Leipzig y Leyden, y luego fue protonotario en su ciudad natal, desempeñando también una vicaría. En su Nucleus Emblematum reúne dos centurias de emblemas en un solo volumen: la primera, sin fecha de impresión, no ofrece más que los emblemas con un texto latino; la segunda, que lleva la fecha de 1613, está precedida de una traducción en francés de los dísticos latinos. Es difícil precisar si el mercedario padre Asarta conocía la obra del emblemista alemán, dada su escasa difusión, pero algunos jeroglíficos pamploneses parecen estar inspirados en ella.

25 J. Baños de Velasco, L. Anneo Seneca ilustrado en Blasones políticos, y morales. Y su impugnador impugnado de sí mismo, Empresa XIX, Madrid, 1670

26 A. García Rives, Fernando VI y doña Bárbara de Braganza (1748-1759), Madrid, 1917, pp. 7 y 34-35. J. Calvo Poyato, Felipe V, el primer Borbón, Madrid, 1992, pp. 228-29.

${ }_{27}$ D. Fehling, «Noch einmal der passer solitarius und der passer Catulls», Philologus, Tomo CXIII, 1969, pp. $217-24$.

28 Thesaurus Linguae Latinae, vol. X, 1, passer. Leipzig, Teubner, 1988, cols. 605-607. Entre los autores latinos se encuentra Catulo, con sus Poesías, en concreto las $\mathrm{n}^{\circ} 2$ y 3 , aunque en este caso la idea de soledad resulta más ambigua.
} 
Jesús, en el Libro de la Vida, acude al mismo versículo de los Salmos para reflejar la soledad del alma ${ }^{29}$. E igualmente el versículo es glosado por San Juan de la Cruz en su Cántico Espiritual, más concretamente en las Canciones 13-14, en las cuales describe el santo las cinco características del «passer solitarius», haciendo un paralelismo con el alma contemplativa; en la tercera de ellas indica que «ordinariamente está solo y no consiente otra ave alguna junto a sí, sino que, en sentándose junto alguna, luego se va; y así el espíritu en esta contemplación está en soledad de todas las cosas, desnudo de todas ellas, ni consiente en sí otra cosa que soledad en Dịos» ${ }^{30}$.

También en la literatura emblemática se observa la misma identificación, y así Ripa indica que la Soledad debe representarse como una mujer vestida de blanco que lleva en la cabeza un pájaro solitario, viéndose cómo habita en un lugar remoto y apartado de los hombres ${ }^{31}$.

Sin embargo, en el cuerpo del jeroglífico no aparece un ave de pequeño tamaño, sino el pelícano dando su sangre a los pelicanitos. El pelícano es ave que, según relatan numerosos autores, para socorrer en la necesidad a sus hijuelos con su propio pico se hiere, nutriéndoles con su sangre; es pues recogido como símbolo del amor al prójimo, de la piedad y de la caridad, y como tal aparece ya desde los egipcios y en los más importantes pensadores greco-romanos y cristianos. En el contexto cristiano, el mensaje divino que encierra se interpreta como la prefiguración de Cristo, y así aparece recogido por Rollenhagen en el emblema $\mathrm{n}^{\circ} 20$ de la segunda centuria. Sin embargo, en el caso del jeroglífico pamplonés no es la caridad lo que simboliza el pelícano, sino la idea de soledad. Muy probablemente la clave de la representación se encuentra en el Salmo 101, versículos 7 y 8 de la Vulgata: «Similis factus sum pellicano qui habitat in solitudine: factus sum sicut nycticorax in parietinis. Vigilavi, et factus sum sicut passer solitarius in tecto», es decir: «Me he vuelto semejante al pelícano, que habita en la soledad; parézcome al búho en muros derruidos. Paso insomnes las noches, y vivo cual pájaro que se está solitario sobre los tejados». Las aves que aparecen en este pasaje tienen en común ser aves nocturnas que huyen de la luz y aman la soledad, cuyo canto es triste y como quejándose; son otras tantas imágenes de las que se sirve el profeta para significar el más triste y abatido estado. El propio San Agustín, en su obra Enarraciones sobre los Salmos, afirma que Cristo se simboliza en estos tres géneros de aves: en el pelícano al nacer, porque sólo Él nació de madre virgen; en el búho al morir, porque padeció en las tinieblas de los judíos como en una noche; y en el pájaro en la resurrección, porque salió del sepulcro y subió volando al cielo como a su techo ${ }^{32}$. En consecuencia, en estos textos comprobamos cómo el pelícano se convierte en un claro símbolo de la soledad, circunstancia que pudo inducir al emblemista a identificar ambos conceptos.

El Jeroglífico $\mathbf{n}^{\circ} 15$ presenta, bajo el mote «Ut vite consulat», la figura de una serpiente en clara alusión a la virtud de la prudencia (Fig. 11), tal y como recoge el epigrama:

\footnotetext{
${ }^{29}$ En el capítulo 20, versículo 10, Santa Teresa refiere lo siguiente: «Con esta comunicación crece el deseo y el estremo de soledad en que se ve, con una pena tan delgada y penetrativa que, aunque el alma se estava puesta en aquel desierto, que al pie de la letra me parece entonces se puede decir (y por ventura lo dijo el real Profeta, estando en la mesma soledad, sino que como a santo se la daría el Señor a sentir en más excesiva manera): <Vigilavi, ed factus sun sicud passer solitarius yn tecto>; y ansí se me representa este verso entonces, que me parece lo veo yo en mí, y consuélame ver que han sentido otras personas tan gran estremo de soledad, cuantimás tales». Santa Teresa de Jesús, Libro de la Vida, en Obras Completas, Madrid, Biblioteca de Autores Cristianos, 1976, pp. 91-92.

${ }^{30}$ San Juan de la Cruz, Cántico Espiritual, Madrid, Fundación Universitaria Española, 1981, p. 762.

31 C. Ripa, Op. cit., T. II, pp. 320-21.

32 San Agustín, Enarraciones sobre los Salmos, en Obras de San Agustín, Tomo XXI, Madrid, Biblioteca de Autores Cristianos, 1966, pp. 638-42. Dice San Agustín acerca del pelícano: «nace en cierta región solitaria, por lo cual nos es desconocida esta ave. Nace en las soledades, principalmente en las del río Nilo, en Egipto... Todo lo que te dice el salmo de ella es que habita en la soledad... Contemplemos más bien a esta ave en la soledad, pues esto sólo consignó el salmo acerca de ella cuando dijo pelícano en soledad. Yo creo que en esto se da a conocer a Cristo nacido de la Virgen, pues sólo nació Él de Virgen; de aquí la soledad. Nació en la soledad porque sólo Él nació de este modo».
} 


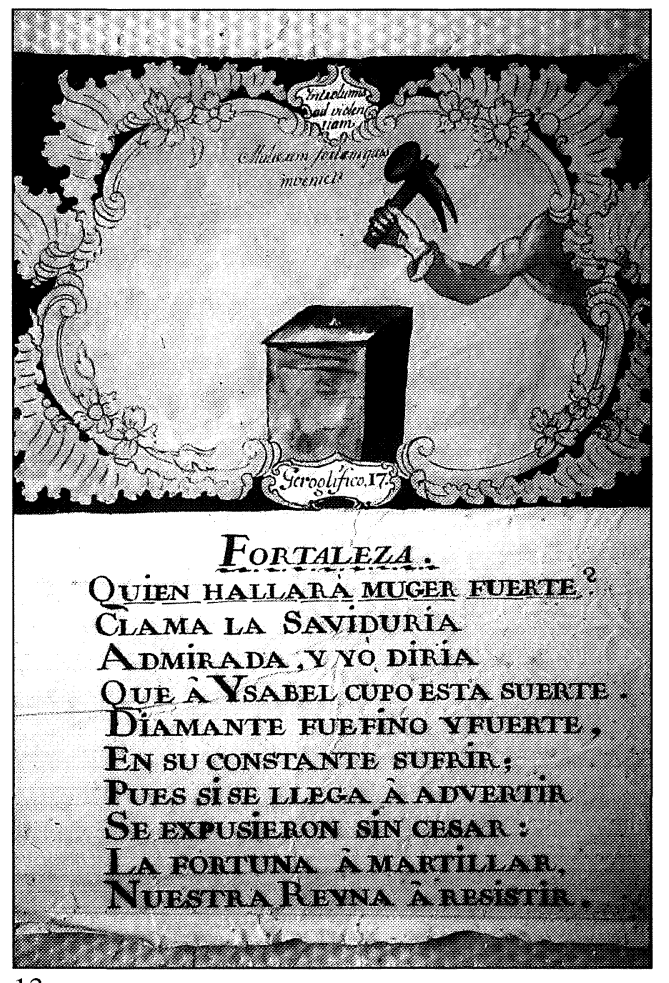

13

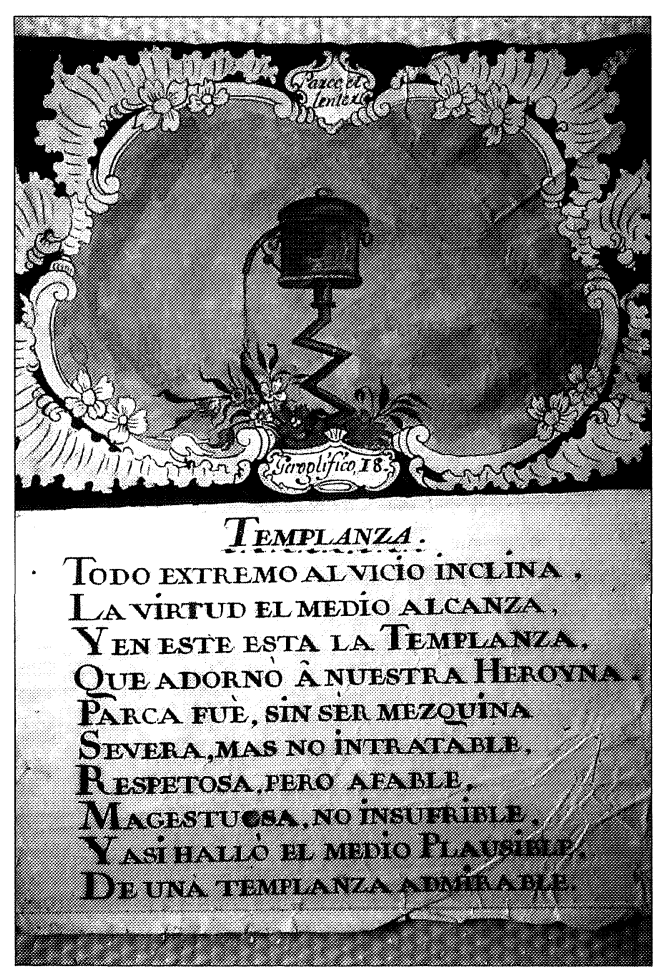

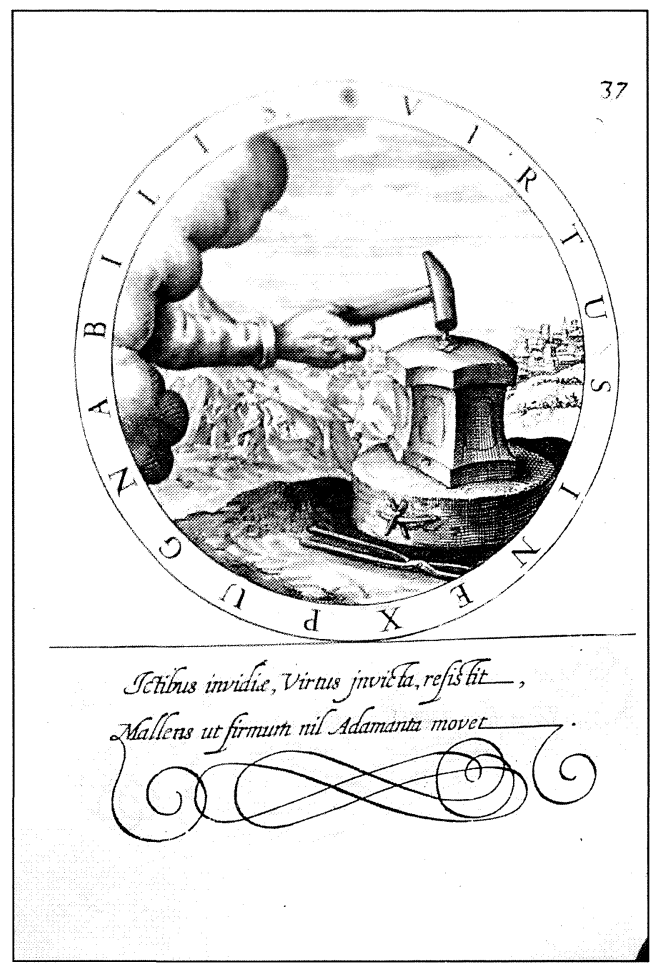

14

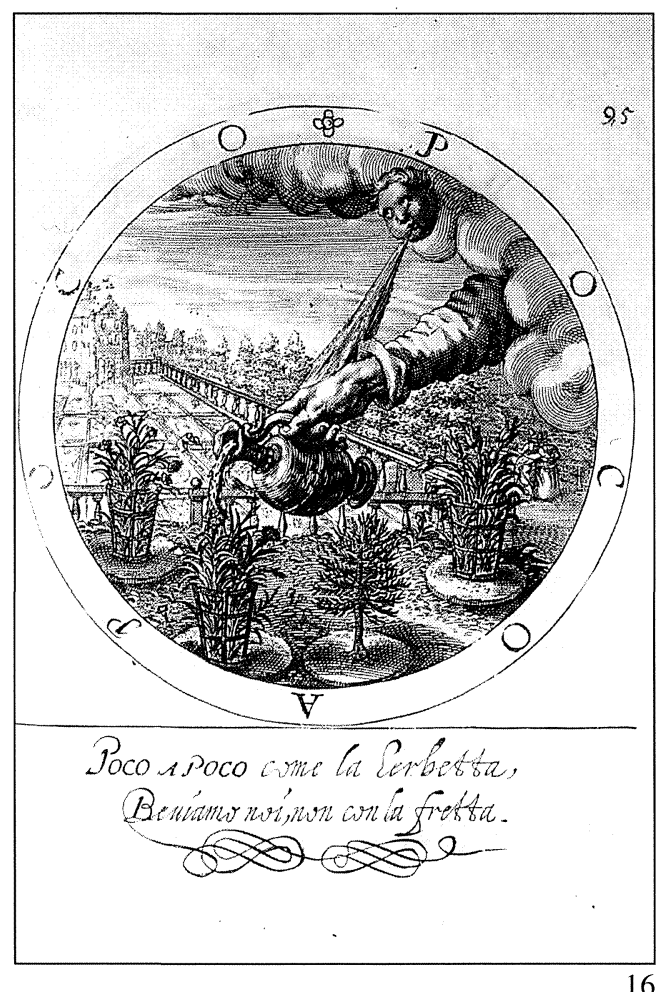

16

Fig. 14. Gabriel Rollenhagen. Nucleus emblematum, emblema $\mathrm{n}^{\circ} 37$ de la segunda centuria.

Fig. 15. Jeroglífico $\mathrm{n}^{\circ} 18$. «Templanza».

Fig. 16. Gabriel Rollenhagen. Nucleus emblematum, emblema $n^{\circ} 95$. 
Cesarán, las insolentes / lisonjas, perjudiciales, /

siendo las Personas Reales / Prudentes, sicut serpentes. /

Siempre aduladoras gentes / Nuestra amada Reyna, abate: /

Todo lisonjero Embate / su oido cerrado halló, /

$\mathrm{Y}$ aun por esso gobernó / Populos in aequitate.

La serpiente ha sido elegida por numerosos emblemistas para representar la virtud de la Prudencia. Ripa la simboliza como una mujer de dos rostros que se mira en un espejo y lleva una serpiente enroscada en el brazo, aludiendo a la frase de las Sagradas Escrituras: «estote prudentes sicut serpentes» (San Mateo 10, 16). Saavedra Fajardo la representa en su empresa XLIV, en la que bajo el lema «Nec a quo nec a quem» aparece una serpiente enroscada que eleva, su cabeza hacia lo alto, indicando que el príncipe debe actuar con tal recato que ni siquiera sus ministros conozcan sus intenciones. No obstante, el epigrama de nuestro jeroglífico se encuentra relacionado más bien con la empresa XLVIII, que tiene por lema «Sub luce luces» y en la que vemos a un reptil de la familia del estelión; en ella Saavedra advierte al príncipe del peligro de aduladores y lisonjeros, cuyos halagos considera más peligrosos que las armas de los enemigos ${ }^{33}$. Así la reina Isabel, siendo prudente como las serpientes, supo mantenerse siempre alejada de toda lisonja y falsa adulación, gobernando a sus súbditos en la virtud y el equilibrio; con este mismo significado de evitar la lisonja aparecerá nuevamente la serpiente en uno de los jeroglíficos del túmulo de Carlos III erigido en Pamplona en 1789.

Por su parte el cuerpo del jeroglífico, con la serpiente arrastrándose por un terreno pedregoso hacia las hendiduras de unas rocas, lo pone en contacto con el emblema 93 de los Emblemas Morales de Sebastián de Covarrubias, en el que figura la serpiente atravesando las estrechas grietas de las rocas despojándose de su vieja piel (Fig. 12). Una representación similar puede observarse también en la empresa 40 de las Empresas morales y espirituales de Francisco de Villava, en la que bajo el mote «Pugnare necesse est» aparece la serpiente como símbolo del mortificado deslizándose entre la angostura de dos piedras para conseguir despojarse de su antigua piel ${ }^{34}$.

El Jeroglífico $\mathbf{n}^{0} 17$ recoge en su cuerpo un brazo humano que con un martillo se apresta a golpear un diamante situado sobre una superficie a modo de yunque (Fig. 13). El mote «Introlumis ad violentiam», al igual que el dístico «Mulierem fortem quis inveniet?», hace referencia a la fortaleza de la reina, como refleja la décima del epigrama:

¿Quién hallará muger fuerte? / Clama la sabiduría / Admirada, y yo diría / que a Ysabel cupo esta suerte. /

Diamante fue fino y fuerte, / En su constante sufrir; /

Pues si se llega a advertir / Se expusieron sin cesar: /

La fortuna a martillar, / Nuestra Reyna a resistir.

En esta ocasión podemos rastrear varias influencias para la composición del jeroglífico. Por un lado debemos tener presente la comparación de Isabel con el diamante para simbolizar su fortaleza. Plinio en su Historia Natural ya afirmaba que su dureza es inexplicable, por cuanto tiene la propiedad de resistir al fuego y de no calentarse jamás; de ahí el nombre que ha recibido, que

\footnotetext{
${ }^{33}$ D. Saavedra Fajardo, Idea de un príncipe político-cristiano representada en cien empresas, Murcia, Real Academia Alfonso X el Sabio, 1994, pp. 292-98 y 322-34. J.M. González de Zárate, «Saavedra Fajardo y la literatura emblemática», Traza y Baza, $\mathrm{n}^{\circ} 10$, pp. 37 y 66-67.

${ }^{34}$ F. de Villava, Empresas espirituales y morales, Baeza, 1613. Empresa Quarenta: «Del mortificado».
} 
en griego significa «fuerza indomable» ${ }^{35}$. La dureza como característica principal del diamante permanece en la literatura posterior; así, en el siglo XIII Alfonso X el Sabio en su Lapidario hacía mención al tema, afirmando del diamante que «es piedra que quebranta todas las otras, horadándolas o cortándolas, pero ninguna otra puede prender en ella» ${ }^{36}$. Tres siglos más tarde Gaspar de Morales, en el capítulo 15 del Libro II de su obra Las virtudes y propiedades maravillosas de las piedras preciosas (1598), afirma que «Diamante en nuestro vulgar lenguaje castellano, es dicho assi, por su gran dureza, como por sus grandes efectos... ni el hierro ni el fuego no ha sido posibles domarle, de donde con justo título fue llamado de los antiguos piedra indómita» ${ }^{37}$.

Por otra parte, el yunque y el martillo o maza han sido utilizados por numerosos emblemistas con la intención de ejemplificar el proverbio popular «cuando eres maza da, cuando yunque sufre». Así por ejemplo, el emblema 78 de los Emblemas Morales de Sebastián de Covarrubias representa una mano que sujeta el martillo con el cual golpea un yunque, dándonos a entender que en la adversidad hemos de tener tolerancia, y en la prosperidad moderación y templanza. Igualmente el emblema 94 recoge estos dos mismos elementos y sobre el yunque un ducado de oro que es quebrado por el martillo, advirtiendo que todas las adversidades que puedan suceder a una persona en esta vida son de poca consideración si mantiene inquebrantable su virtud y honradez. También la empresa $\mathrm{n}^{\circ} 36$ de la primera parte de las Empresas Morales de Juan de Borja muestra dos martillos y un yunque, con el mote «In utrumque paratus», afirmando que es el oficio del yunque sufrir, y el de los martillos herir, haciendo referencia al hombre discreto y prudente que sabe sufrir o ejecutar, acometer o esperar, según las ocasiones que se le presenten ${ }^{38}$; para S. Sebastián, la fuente de inspiración de la empresa la encuentra Juan de Borja en el emblema LVII de Le theatre des bons engins, obra del emblemista francés Guillaume de la Perrière ${ }^{39}$. De igual forma, en las Empresas de los reyes de Castilla y de León, de Francisco de la Reguera, la empresa $n^{\circ}$ XVI, dedicada a Fernando el Católico, presenta bajo el lema «Tempori cede» una mano que sujeta un martillo o maza con la que se apresta a golpear un yunque; con ella hace referencia a una de las cualidades políticas que adornaban al monarca, como es la capacidad de adaptarse a las cambiantes circunstancias por las que atravesó el Estado, sobre todo en su etapa de regente viudo, basando su virtud en la prudencia, fortaleza y capacidad de sufrimiento ${ }^{40}$.

Asimismo pueden verse el yunque y el martillo en el emblema XLIII de la Emblemata Regio Politica de Juan de Solórzano (1653). Sumamente interesante resulta el documento LIV del Príncipe perfecto y Ministros Aiustados del jesuita Andrés Mendo, en el que con el lema «Tempori cede», aparece un brazo con un martillo que golpea en el yunque, en alusión al sufrimiento y paciencia del príncipe, quien además es comparado con el diamante ${ }^{41}$. Sin embar-

\footnotetext{
${ }^{35}$ Pline l'ancien, Histoire naturelle, Livre XXXVII, París, 1981, pp. 57-60. Tradicionalmente el diamante se ha venido identificando con la fortaleza, aunque también puede desarrollar otros significados como la caridad, la necesidad o la crueldad. Un amplio estudio acerca del significado de las piedras preciosas en el lenguaje emblemático lo constituye el de V. Mínguez, «El lenguaje emblemático de las gemas», Literatura Emblemática Hispánica. Actas del I Simposio Internacional, pp. 559-67.

${ }^{36}$ El primer Lapidario de Alfonso X el Sabio, Madrid, Edilan, 1982, p. 41.

${ }^{37}$ G. de Morales, Las virtudes y propiedades maravillosas de las piedras preciosas, Madrid, Editora Nacional, $1977, \mathrm{pp}$. 276-85.

${ }^{38}$ J. de Borja, Empresas morales, Edición e introducción de Carmen Bravo-Villasante, Madrid, Fundación Universitaria Española, 1981, pp. 72-73.

${ }^{39}$ S. Sebastián, «Influencias e interferencias en los orígenes de la emblemática española», Actas del I Simposio Internacional de Emblemática, pp. 447-48.

${ }^{40}$ B. García Vega, «Las empresas de los reyes de Castilla y de León de Francisco de la Reguera», Actas del I Simposio Internacional de Emblemática, pp. 113,133 y 146.

${ }_{41}$ «Es necesario sufrir, como yunque, los golpes de la adversa fortuna con disimulación, y paciencia; siendo el pecho Real un diamante, a quien el más duro y violento golpe no doble». A. Mendo, Príncipe Perfecto y Ministros Aiustados, Documentos políticos y morales. En emblemas, Leon de Francia, 1662. Documento LIV.
} 
go, el antecedente más directo del jeroglífico pamplonés lo encontramos nuevamente en el Nucleus emblematum de Rollenhagen, quien en el emblema $\mathrm{n}^{\circ} 37$ de la segunda centuria presenta, bajo el mote «Virtus inexpugnabilis», la imagen del diamante resistiendo a los golpes del martillo, en clara alusión a la virtud que triunfa sobre el vicio ${ }^{42}$ (Fig. 14).

Otro de los jeroglíficos conservados de las exequias de Isabel de Farnesio es el $\mathbf{n}^{\mathbf{0}} \mathbf{1 8}$, y en él apreciamos una regadera o jarra que riega con mesura un bello ramillete de flores (Fig. 15). Bajo el mote «Parce, et lenter», el emblemista alude a la templanza de la reina, y así lo recogen los versos del epigrama:

Todo extremo al vicio inclina, / la virtud al medio alcanza, /

Y en éste está la Templanza, / Que adornó a nuestra Heroyna. /

Parca fue, sin ser mezquina. / Severa, mas no intratable, /

Respetuosa, pero afable, / Magestuosa, no insufrible, /

Y así halló el medio Plausible, / De una templanza admirable.

El jeroglífico pamplonés se aleja de la representación tradicional de la Templanza, personificada en una mujer que porta distintos atributos alusivos a la equilibrada moderación y al dominio de las pasiones y sentidos, tal y como la representa Ripa en su Iconología ${ }^{43}$. En nuestro caso parece conectar más bien con la imagen del campo con flores como emblema de virtudes, de tal manera que su riego se convierte en el símbolo del esfuerzo constante del príncipe por conseguir que en su estado florezca la virtud ${ }^{44}$. Así, Saavedra Fajardo, en su empresa XXXIV, «Ferendum et sperandum», presenta una jarra que derrama agua sobre un rosal todavía sin florecer plantado en un vaso. Igualmente, la jarra o campo con flores que recibe agua aparece en ciertas divisas de libreros acompañada del mote «poco a poco», dando a entender que quien riegue con constancia obtendrá los frutos deseados; con este significado la propone Rollenhagen en su emblema $n^{\circ} 95$ (Fig. 16). En este sentido, debemos hacer notar el paralelismo existente entre el lema «poco a poco», y el que figura en el jeroglífico de Isabel, «parce, et lenter», ya que ambos ofrecen un significado muy parecido. También Andrés Mendo, en su Príncipe perfecto, emplea en ocasiones como detalle decorativo una jarra de bello diseño que derrama su agua sobre un ramillete de flores ${ }^{45}$.

El último jeroglífico farnesino ha perdido lema y cuerpo y tan sólo ha llegado hasta nosotros el epigrama dedicado a la tristeza por la muerte de la reina; en este caso se juega con la palabra «LLOREMOS», cuyas primeras letras estaban compuestas a modo de acróstico, en tanto que las dos últimas eran comunes para todos los versículos:

Los pechos quebrantad-

Los corazones de dolor perdid-

Oy en llanto anegad-

Rompiendo el ayre en funebres gemid-

Entonen de horror llen-

Mortales ayes en funetos tren-

\footnotetext{
${ }^{42}$ G. Rollenhagen, Op. cit., Centuria Segunda (1613), Emblema n ${ }^{\circ} 37$. En su explicación al emblema afirma: «La invencible virtud se mantiene activa contra la envidia, sin doblegarse al peligro más inmediato, como el diamante nunca quiere ceder al golpe del martillo que jamás lo domina».

${ }^{43}$ C. Ripa, Op. cit., T. II, pp. 353-55.

44 J.M. González de Zárate, Op. cit., p. 44.

45 Otro emblemista que incluye en su repertorio la regadera que vierte agua sobre las flores es Zincgreff, en el emblema 61 de su Emblematum Ethico-Politicorum Centuria (1619).
} 